\title{
Strategi Bauran Pemasaran 4P Dalam Menentukan Sumber Modal Usaha Syariah Pedagang Pasar di Sidoarjo
}

\author{
Desy Dwi Sulastriya Ningsih"), M. Ruslianor Maika ${ }^{2)}$ \\ ${ }^{1,2}$ Fakultas Agama Islam, Universitas Muhammadiyah Sidoarjo \\ *Email korespondensi: desydwisulastriyaningsih@gmail.com
}

\begin{abstract}
This research discussed the two main reasons that could be affecting decisions market traders in choosing a source of their capital, which is based on the needs of business capital and marketing with marketing mix 4P. The data obtained through interviews with traditional market traders in the Sidoarjo district using the qualitative method from a phenomenology perspective. This study using primary data analyzed that processed in-app atlas.ti 9 to achieve the structure and efficient data. This study aims to determine the effect of the 4P Marketing Mix carried out by financial institutions in attracting traders to choose the source of their business capital and whether traders' knowledge of usury and Islamic financial institutions can change this decision. The conclusions obtained indicate that public knowledge about riba and Islamic banking does not influence in determining people's interest in choosing the source of business capital, while the marketing mix can attract traders in determining where they will make business resource loans.
\end{abstract}

Keywords : marketing mix, bussines capital, market traders, atlas.ti-9

Saran sitasi: Ningsih, D. D. S., \& Maika, M. R. (2020). Strategi Bauran Pemasaran 4P Dalam Menentukan Sumber Modal Usaha Syariah Pedagang Pasar di Sidoarjo. Jurnal Ilmiah Ekonomi Islam, 6(03), 693-702. doi:http://dx.doi.org/10.29040/jiei.v6i3.1464

DOI: http://dx.doi.org/10.29040/jiei.v6i3.1464

\section{PENDAHULUAN}

Penelitian ini membahas mengenai 2 alasan utama yang dapat mempengaruhi keputusan pedagang pasar dalam memilih sumber modal usahanya. Kebutuhan akan modal usaha menjadi salah satu alasan bagi para pedagang untuk memilih mengajukan pinjaman guna memenuhi kebutuhannya yang mendesak, seperti mengembangkan usaha, makanan, pendidikan, dan jasa lainnya (Munizu, 2012)(Maesaroh, 2016)(Hakim \& Mulyani, 2017). Untuk memenuhi permintaan akan kebutuhan tersebut, maka terjadi persaingan diantara beberapa bank dalam menarik minat nasabah dimana faktor bauran pemasaran (marketing mix) $4 P$ menjadi salah satu penentu yang akhirnya membuat masyarakat masih mempertimbangkan, bahkan mengurungkan niatnya untuk memilih Bank Syariah sebagai solusi dari permasalahan yang dihadapi (Andespa, 2017) (Rahmawati, Kafid, \& Wijaya, 2017).

Kebutuhan menjadi salah satu alasan yang mendasari seseorang dalam berperilaku, dimana kebutuhan merupakan dorongan yang paling kuat dalam mengarahkan seseorang untuk melakukan tindakan ke arah tercapainya suatu tujuan (Palisoa, Andayani, \& Maduwinarti, 2009). Kebutuhan merupakan keinginan seseorang terhadap suatu barang/jasa yang apabila tidak dipenuhi makan akan memberikan dampak negatif seperti halnya kelaparan, kedinginan, atau sakit yang bertambah parah. Pada dasarnya, manusia memiliki banyak kebutuhan yang beraneka ragam, bahkan kebutuhan tersebut akan terus bertambah seiring berkembangnya peradaban, ilmu pengetahuan dan tekhnologi (Rochmawan, 2008). Selain itu, manusia juga memerlukan modal usaha dalam rangka menunjang usahanya dalam memenuhi kebutuhan sehari-hari. Secara harfiah modal usaha merupakan uang/barang yang dapat digunakan sebagai dasar untuk melakukan suatu pekerjaan dimana hal tersebut merupakan salah satu investasi jangka pendek ataupun investasi pada harta lancar (current asset) (Abbas, 2018). Bagi para pelaku usaha termasuk pedagang, sumber modal usaha 


\section{Jurnal Ilmiah Ekonomi Islam, 6(03), 2020, 694}

merupakan hal yang sangat penting, karena dengan adanya modal usaha keberlangsungan usahanya akan tetap terjaga sehingga kebutuhan-kebutuhan lainnya juga dapat terpenuhi.

Berikutnya adalah strategi pemasaran yang dilakukan oleh lembaga keuangan dalam menarik minat nasabah yang harus dilakukan berdasarkan fenomena yang terjadi dengan tujuan memberikan barang dan jasa yang dibutuhkan oleh konsumen di waktu yang tepat dengan harga yang terjangkau tetapi tetap menguntungkan perusahaan (Fuad, H, Nurlela, Sugiarto, \& Paulus, 2006). Sebuah organisasi ataupun perusahaan bertugas untuk memenuhi keinginan, kebutuhan, serta minat target sasaran sehingga dapat memberikan kepuasan dengan lebih efektif dan efisien. Aktifitas pemasaran dapat dilakukan dengan beberapa pendekatan, salah satunya adalah bauran pemasaran (Marketing Mix). Menurut McCarthy aktivitas Bauran Pemasaran (Marketing Mix) terdiri dari 4 kategori, yaitu: (Sefudin, 2014)

a. Produk (Product)

Segala sesuatu yang ditawarkan untuk memenuhi kebutuhan pasar yang melingkupi kualitas, ciri, merk, kemasan, pelayanan, garansi, dan lainnya. Produk merupakan hal paling penting dalam strategi marketing yang harus diperhatikan oleh sebuah perusahaan dalam memasarkan barang maupun jasanya, karena melalui hal inilah perusahaan dapat menarik minat konsumen dengan memberikan produk yang sesuai kebutuhan, memiliki mutu terbaik, berkinerja, ataupun inovatif.

b. Harga (Price)

Nilai dari suatu barang yang diukur dengan uang, termasuk daftar harga, promo, jangka waktu pembayaran, syarat kredit. Harga memegang peranan penting dalam proses terjadinya kesepakatan dalam jual beli. Dalam menentukan pilihan, harga tentunya menjadi salah satu hal yang dipertimbangkan.

c. Tempat (Place)

Berkaitan dengan proses distribusi yang merupakan kegiatan perusahaan yang saling berkaitan agar dapat menjadikan suatu prduk/jasa siap digunakan atau dikonsumsi, dalam hal ini termasuk lokasi, persediaan transportasi, dan cakupan pasar. Tempat yang startegis dan mudah dijangkau tentunya juga menjadi faktor pendukung terhadap keputusan membeli suatu barang/jasa.

\section{d. Promosi (Promotion)}

Promosi merupakan bagian dari komunikasi yang bertujuan memberikan penjelasan agar dapat meyakinkan calon nasabah/konsumen mengenai barang/jasa yang ditawarkan. Proses pemasaran ini dapat dilakukan dengan cara periklanan, public relation, dan tenaga penjualan. Kegiatan promosi menjadi faktor pendukung lainnya terhadap keberhasilan pemasaran suatu produk/jasa.

Sebagai Negara dengan mayoritas penduduk muslim tebesar, munculnya lembaga keuangan syariah menjadi jawaban akan adanya tuntutan pasar terhadap kebutuhan masyarakat yang meyakini islam sebagai way of life, sehingga munculnya industry perbankan syariah diharapkan dapat mengakomodir adanya layanan jasa keuangan yang dijalankan dengan nilai moral dan berdasarkan prinsip syariah (Saputra \& Ghani, 2016). Hingga akhir tahun 2019 jumlah lembaga keuangan syariah di Indonesia terus mengalami peningkatan dimana tercatat sebanyak 14 Bank Umum Syariah (BUS), 20 Unit Usaha Syariah (UUS), dan 164 Bank Pembiayaan Rakyat Syariah (BPRS) (KNKS, 2020). Akan tetapi meskipun pertumbuhan LKS di Indonesia dinilai cukup baik, hal tersebut justru berbanding terbalik terhadap minat masyarakat menggunakan jasa lembaga keuangan syariah. Beberapa sebab yang membuat hal tersebut terjadi adalah kurangnya fasilitas layanan, promosi, dan tingkat pengetahuan terhadap kurangnya minat masyarakat menggunakan produk bank syariah. (Winarni, n.d.)

Sehingga berdasarkan permasalahan diatas, peneliti tergerak untuk melakukan analisis mengenai "Strategi Bauran Pemasaran 4P Dalam Menentukan Sumber Modal Usaha Syariah Pedagang Pasar di Sidoarjo" yang bertujuan untuk mengetahui dampak Bauran Pemasaran (Marketing Mix) 4P yang dilakukan oleh lembaga keuangan untuk dapat menarik minat para pedagang dalam memilih sumber modal usahanya dan apakah pengetahuan tentang riba dan lembaga keuangan syariah yang dimiliki para pedagang dapat mengubah keputusan tersebut.

\section{METODE PENELITIAN}

Penelitian ini merupakan penelitian kualitatif dengan perspektif fenomenologi yang menggunakan data primer, dimana data primer tersebut merupakan hasil wawancara langsung terhadap 40 pedagang pasar 


\section{Jurnal Ilmiah Ekonomi Islam, 6(03), 2020, 695}

tradisional yang ada di Kabupaten Sidoarjo. Pemilihan ke 40 responden tersebut dilakukan dengan teknik snowball sampling, dimana peneliti memulai dengan mewawancarai 2 narasumber, kemudian narasumber tersebut menunjuk kepada narasumber lainnya sehingga sampel menjadi semakin banyak sampai informasi dan data yang dibutuhkan peneliti dapat terpenuhi. Kemudian Penelitian kualitatif digunakan sebagai metode untuk memahami secara mendalam sebuah peristiwa yang terjadi dalam kehidupan sosial (Hamid, 2013). Selain itu, metode ini bertujuan untuk menjelaskan sebuah fenomena yang terjadi dari berbagai karakter yang melingkupi dengan mengedepankan apa daripada mengapa dan bagaimana hal tersebut dapat terjadi (Nassaji, 2015). Dengan menggunakan perspektif fenomenologi maka fenomena tersebut dapat digambarkan dan dideskripsikan secara apa adanya tanpa adanya manipulasi sehingga peneliti harus bersikap netral agar diperoleh hasil yang bernilai tinggi.

Penelitian ini dilakukan di beberapa lokasi yaitu, Pasar Tradisional Baru Porong, Pasar Tradisional Tanggulangin, Pasar Tradisional Balongdowo Candi, dan Pasar Tradisional Induk Larangan. Hasil data wawancara yang diperoleh kemudian di proses menggunakan software Atlas.ti 9 sehingga data tersebut dapat memberikan hasil analisis secara terstruktur dan efisien.

\section{HASIL DAN PEMBAHASAN}

\subsection{Hasil penelitian}

Pada penelitian ini, peneliti berhasil mengumpulkan data (wawancara) dari 40 pedagang yang tersebar di beberapa pasar tradisional yang ada di Kabupaten Sidoarjo. Wawancara tersebut dilakukan dengan 2 cara yaitu wawancara secara langsung kepada 33 pedagang, sedangkan 7 pedagang lainnya melalui wawancara by phone. Berdasarkan hasil analisis deskriptif yang telah dilakukan, dapat diperoleh gambaran umum karakteristik narasumber berdasarkan jenis kelamin yaitu:

Tabel 1. Karakteristik Narasumber Berdasarkan Jenis Kelamin

\begin{tabular}{|c|c|c|c|}
\hline No. & $\begin{array}{c}\text { Jenis } \\
\text { Kelamin }\end{array}$ & Frekuensi & $\begin{array}{c}\text { Persentase } \\
(\boldsymbol{\%})\end{array}$ \\
\hline 1. & Perempuan & 34 & $85 \%$ \\
\hline 2. & Laki-Laki & 6 & $15 \%$ \\
\hline & Jumlah & 40 & $100 \%$ \\
\hline
\end{tabular}

Dari tabel diatas dapat diketahui bahwa pedagang perempuan berjumlah 34 orang sedangkan pedagang laki-laki sebanyak 6 orang. Hal ini menunjukkan bahwa pedagang berjenis kelamin perempuan lebih mendominasi pasar, sehingga kecenderungan tergiur akan suatu penawaran lebih besar. Kemudian berdasarkan karakteristik sumber modalnya, dapat diketahui sebagai berikut:

\section{Sumber Modal Usaha}

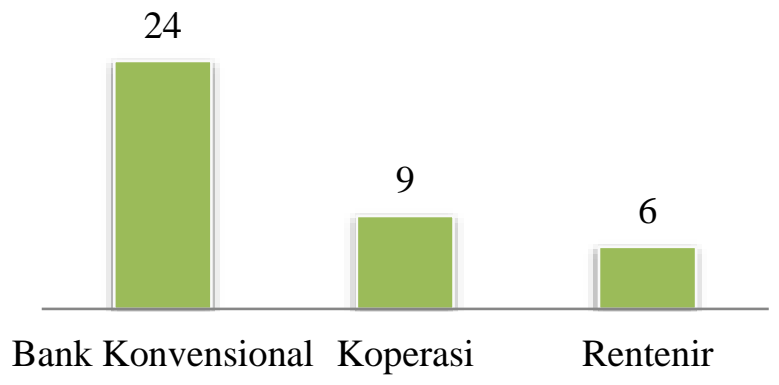

Gambar 1. Karakteristik Narasumber Berdasarkan Modal Usaha

Sumber: Data Primer Diolah

Setidaknya ada 3 sumber modal usaha yang dipilih para pedagang untuk membantu menunjang keberlangsungan usahanya, yaitu sebanyak 24 pedagang memilih mengajukan pembiayaan pada Bank Konvensional, kemudian pada koperasi sebanyak 9 orang, dan rentenir 6 orang. Data tersebut menunjukkan bahwa sebagian besar pedagang lebih memilih mengajukan pembiayaan pada bank konvensional dan tidak ada satupun pedagang yang memilih menggunakan produk pembiayaan pada lembaga keuangan syariah baik bank syariah maupun koperasi syariah.

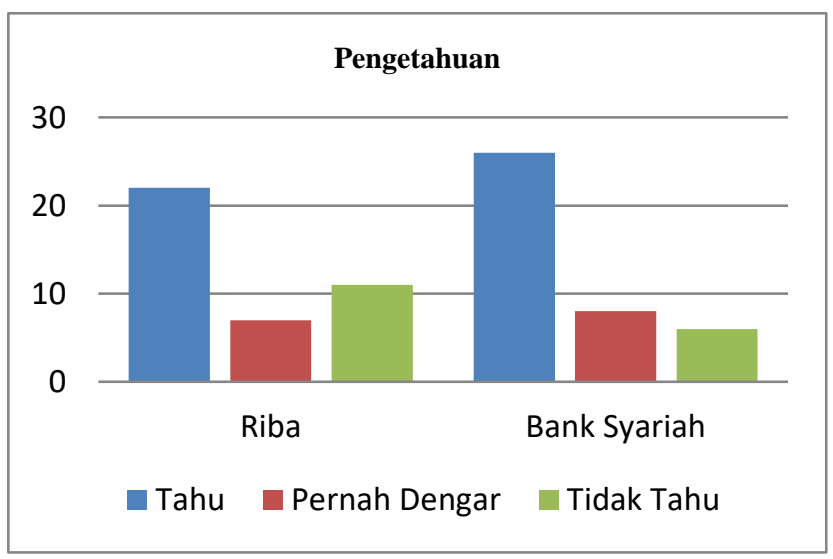

Gambar 2. Pengetahuan Narasumber Sumber: Data Primer Diolah 


\section{Jurnal Ilmiah Ekonomi Islam, 6(03), 2020, 696}

Kemudian berdasarkan gambar diatas dapat diketahui bahwa sebanyak 22 pedagang mengaku mengetahui apa itu riba. Bahkan mengetahui bahwa riba merupakan suatu dosa besar yang harus ditinggalkan. Kemudian 7 orang diantaranya mengatakan pernah mendengar istilah riba, akan tetapi mereka tidak begitu yakin apa yang dimaksud dengan riba. Lalu sisanya yaitu 11 orang, mengaku tidak mengetahui apa yang dimaksud dengan riba.

Begitupun dengan pengetahun akan bank syariah. Sebagian besar pedagang yaitu sebanyak 26 orang mengaku tahu adanya bank syariah di sekitar mereka dan tahu bahwa bank syariah merupakan suatu lembaga keuangan yang kegiatan operasionalnya berdasarkan prinsip syariah. Selanjutnya 8 orang mengaku pernah mendengar tetapi tidak mengetahui pasti bagaimana bank syariah. Kemudian 6 pedagang lainnya mengatakan tidak tahu mengenai bank syariah.

\subsection{Pembahasan}

Selajutnya peneliti melakukan analisis data dengan lebih mendalam menggunakan software atlas.ti 9 terhadap fenomena yang terjadi dimana kemudian meghasilkan data berupa jaringan atau network seperti pada gambar berikut ini.

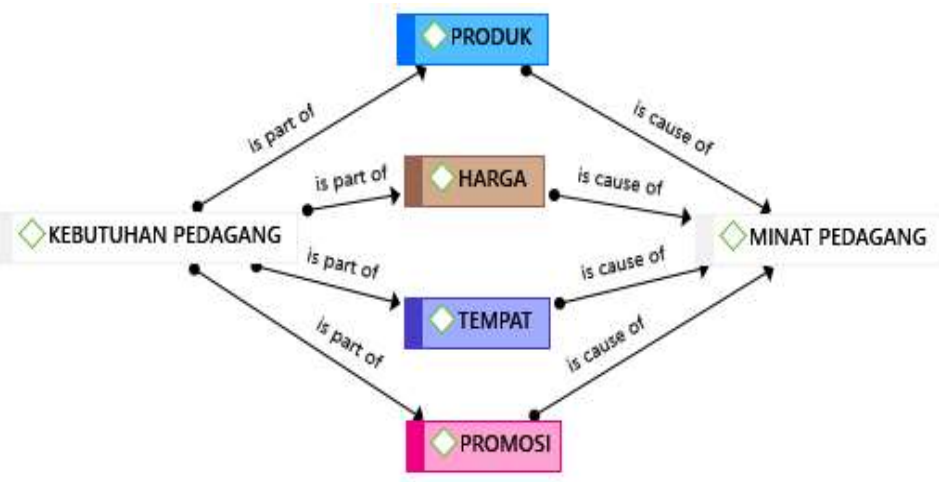

Gambar 3. Network Bauran Pemasaran

Sumber: Data Primer Diolah menggunakan software Atlas.ti 9

Gambar diatas menunjukkan bahwa, sebelum para pedagang memutuskan untuk melakukan pinjaman modal usaha, kebutuhan menjadi pemicu awal akan adanya keinginan untuk melakukan pinjaman. Dari hasil analisis tersebut diketahui ada 3 kategori kebutuhan yang disampaikan oleh pedagang.

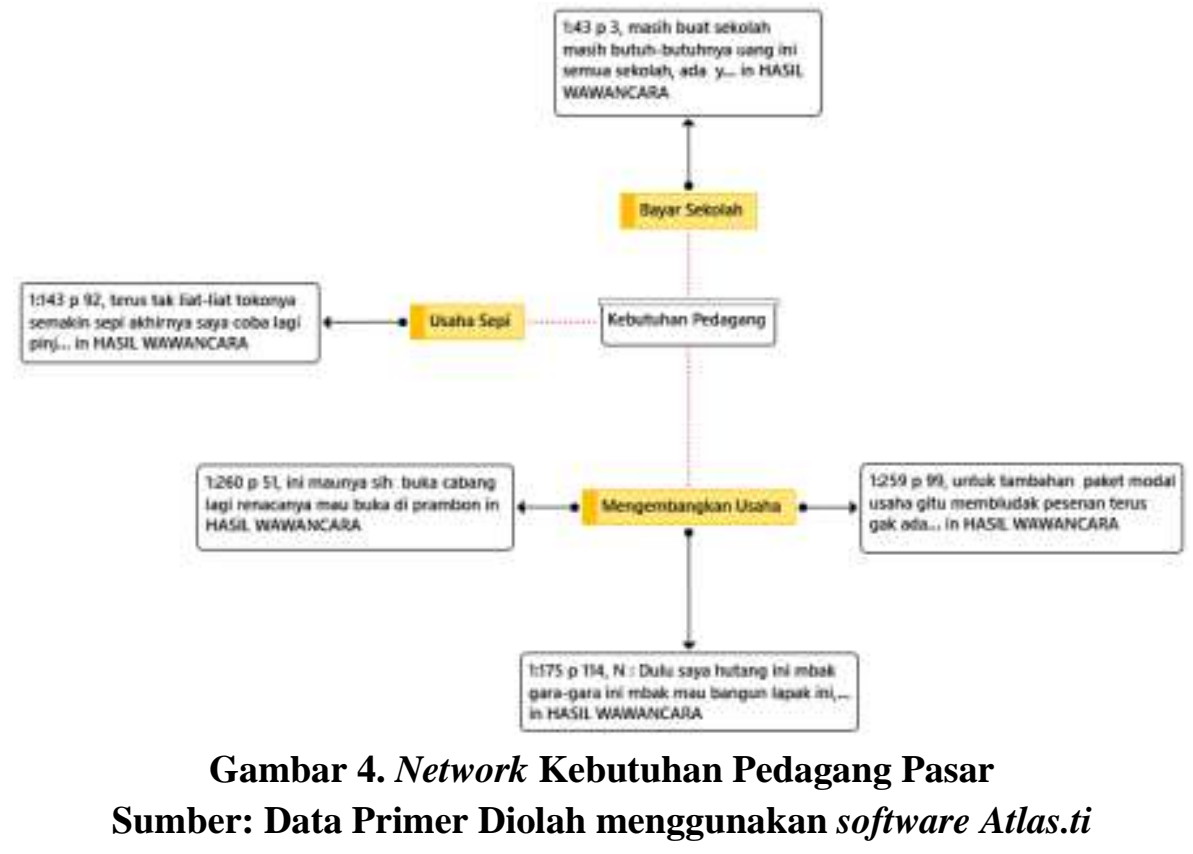

Pertama, yaitu mengembangkan usaha. Mengembangkan usaha merupakan kebutuhan yang banyak diutarakan oleh mayoritas pedagang. Menurut para pedagang, modal usaha yang diperoleh akan digunakan untuk menambah jumlah barang dagangannya. Hal ini dikarenakan meningkatnya jumlah pesanan sehingga mau tidak mau harus meminjam karena keterbatasan modal yang dimiliki. 
Kemudian meningkatnya jumlah peminat produk usaha, membuat pedagang merasa perlu memperluas usaha dengan membuka cabang di tempat lain. Hal ini merupakan salah satu cara yang digunakan untuk mendekati konsumen, sehingga dapat meningkatkan pemasukan yang nantinya akan diperoleh. Selanjutnya beberapa dari mereka juga mengatakan akan menggunakan pinjaman modal usaha tersebut untuk merenovasi toko yang awalnya hanya warung kecil menjadi toko yang lebih besar.

Kedua, yaitu menurunnya jumlah pengunjung dan peminat yang menyebabkan usaha menjadi sepi. Mereka mengaku bingung mengahadapi situasi tersebut, ditambah adanya wabah covid-19 yang memperparah keadaan membuat mereka tidak memiliki pilihan lain, selain melakukan pinjaman pada lembaga keuangan konvensional. Rata-rata pedagang tersebut merupakan nasabah lama dari lembaga keuangan konvensional tersebut sehingga dalam proses pengajuannya relatif lebih cepat.

Ketiga yaitu untuk membayar biaya sekolah juga menjadi alasan pedagang untuk mengajukan ataupun

memperpanjang pinjamannya di lembaga keungan konvensional. Mereka mengaku biaya sekolah dan pondok pesantren membutuhkan dana yang cukup besar, yang mana dana tersebut dibutuhkan dalam waktu yang cepat, sehingga mereka perlu melakuan pinjaman pada lembaga keungan konvensional agar kebutuhan tersebut dapat segera terpenuhi.

Sehingga berdasarkan hal tersebut lembaga keuangan konvensional menggunkan strategi pemasaran dengan pendekatan bauran pemasaran atau marketing mix 4P (Product, Price, Place, Promotion) sebagai usaha memenuhi kebutuhan pedagang yang telah disebutkan diatas sehingga dapat menarik minat pedagang untuk memilih sumber modal usaha.

\section{Product (Produk)}

Dalam hal ini diketahui bahwa produk yang ditawarkan oleh Lembaga Keuangan Konvensional terutama Bank Konvensional memiliki 3 keunggulan yang membuat para pedagang memilih meminjam modal usaha di Bank Konvensional yaitu, program yang ditawarkan, pelayanan, dan kemudahan serta kecepatannya.

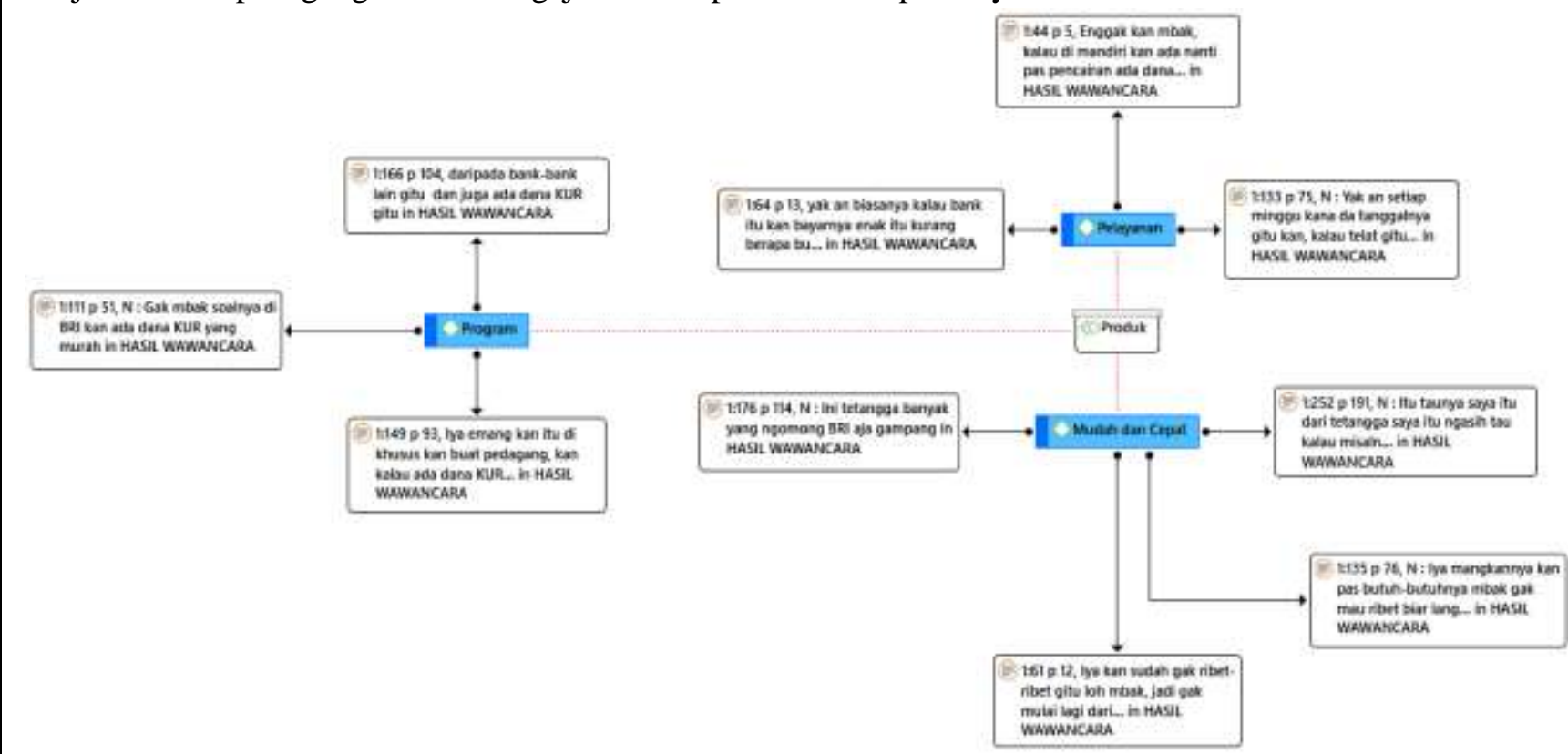

Gambar 5. Network Produk Lembaga Keuangan Sumber: Data Primer Diolah menggunakan software Atlas.ti 9

Adanya Program KUR (Kredit Usaha Rakyat) yang diperuntukkan bagi para pedagang kecil dan UMKM memberikan daya tarik tersediri bagi mayoritas pedagang. Menurut pendapat beberapa pedagang, adanya program dana KUR ini membuat mereka tidak ingin mencoba bank-bank yang lain, dan lebih memilih melakukan pinjaman di bank BRI saja yang merupakan salah satu bank konvensional yang memberikan penawaran program tersebut. Hal ini dikarenakan dana KUR dapat memberikan keuntungan bagi para pedagang dari sisi harga yang murah dan kecilnya bunga yang ditetapkan. Beberapa pedagang juga mengatakan bahwa adanya dana KUR dapat meringankan beban yang ditanggung oleh pedagang.

Kemudian mudah dan cepatnya pelayanan yang diberikan baik dari sisi proses pengajuan maupun dari sisi pencairan dananya, membuat para pedagang 


\section{Jurnal Ilmiah Ekonomi Islam, 6(03), 2020, 698}

semakin yakin untuk memilih melakukan pinjaman di lembaga keuangan konvensional. Mayoritas pedagang mengatakan bahwa proses pengajuan pinjamannya sangat memudahkan pedagang dalam mengurusnya, apalagi jika pedagang sebelumnya sudah pernah mengajukan atau sudah menjadi nasabah, maka akan lebih mudah untuk proses pengajuan lagi karena tidak perlu repot-repot untuk melakukan survey ulang, sehingga para pedagang enggan berpindah kepada lembaga keuangan lainnya. Selain itu juga, proses pencairan dana pinjaman yang diajukan tidak membutuhkan waktu yang lama, mengingat mereka memerlukan dana cepat sehingga kebutuhan mendesak yang dihadapi oleh pedagang dapat dengan segera tertangani.

Selanjutnya pelayanan yang diberikan kepada nasabah juga menjadi nilai lebih. Jika dalam perjalanannya, nasabah mengalami kesulitan dalam pembayaran maka pihak bank akan mendatangi

nasabah dan memberikan keringanan dengan memberikan tenggang waktu dalam proses pembayaran. Kemudian adanya pengendapan dana di awal pencairan pinjaman sebagai salah satu mitigasi risiko yang dilakukan bank apabila di tengah jalan nasabah mengalami telat bayar. Maka kekurangan pembayarannya akan diambilkan dari dana tersebut. Hal ini tentu saja memberikan keringanan bagi para pedagang dalam menyelesaikan pinjamannya. Disamping itu juga adanya penawaran pinjaman lagi bagi nasabah yang pinjamannya akan selesai, memberikan nilai lebih bagi sebagian pedagang yang memang masih membutuhkan modal usaha.

\section{Price (Harga)}

Berikut ini adalah alasan yang disampaikan para pedagang pasar mengapa lebih memilih melakukan pinjaman modal usaha di Bank Konvensional karena harga yang ditawarkan lebih terjangkau.

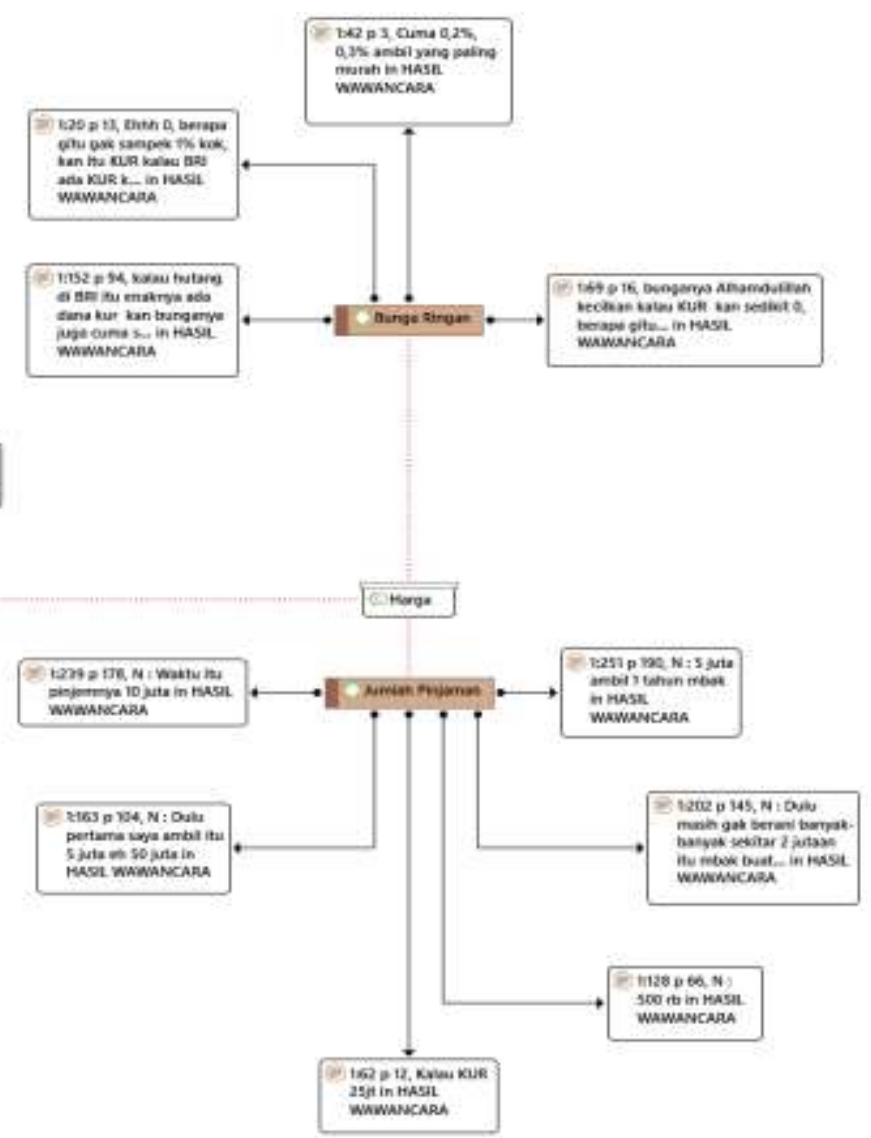

Gambar 6. Network Harga

\section{Sumber: Data Primer Diolah menggunakan Atlas.ti}

Menurut penuturan para pedagang jumlah pinjaman yang dapat diajukan di koperasi yaitu berkiasar antara 500 ribu hingga 2 juta yang mana jumlah tersebut dapat diangsur mingguan oleh para pedagang. Rata-rata para pedagang dapat mengangsur selama 15 kali hingga 20 kali. Kemudian untuk dana
KUR yang ditawarkan oleh BRI, para pedagang mngajukan pinjaman dengan kisaran antara 5 juta hingga 50 juta, dengan nominal yang sering diajukan adalah 10 juta dan 25 juta. Nominal terebut dapat dicicil setiap bulan dalam kurun waktu 1 sampai 3 tahun. 
Kemudian untuk bunganya, para pedagang menyatakan bunga yang ditetapkan oleh bank cukup rendah. Pasalnya untuk dana KUR bunganya hanya sekitar $0,1 \%$. Dengan bunga yang tidak sampai $1 \%$ tentu membuat pedagang merasa lebih ringan dan hal tersebut akan mempengaruhi jumlah cicilan yang setiap bulannya dikeluarkan. Nominal cicilan perbulan yang dikeluarkan oleh para pedagang akan berbeda dengan satu dan lainnya, tergantung dengan jumlah pinjaman dan jangka waktunya. Misalkan saja Ibu Zahiriyah seorang pedagang sepatu wanita di Pasar Induk Larangan, beliau mengatakan bahwa telah mengajukan pinjaman dana KUR sebesar Rp.
25.000.000 yang dicicil selama 24 bulan dengan nominal cicilan perbulannya Rp. 1.120.000. Senada dengan penuturan Ibu Dewi seorang pedagang sembako di Perumahan Griya Surya Asri yang meminjam dana KUR Rp. 10.000 .000 selama 12 bulan dengan cicilan perbulan Rp. 900.000. Mereka pun mengakui, bahwa harga yang ditawarkan tersebut lebih murah daripada harga yang ditawarkan oleh Bank Syariah.

\section{Place (Tempat)}

Sebagian besar pedagang memilih untuk menggunakan fasilitas lembaga keuangan yang ada disekitar lingkungan tempat tinggal ataupun usahanya.

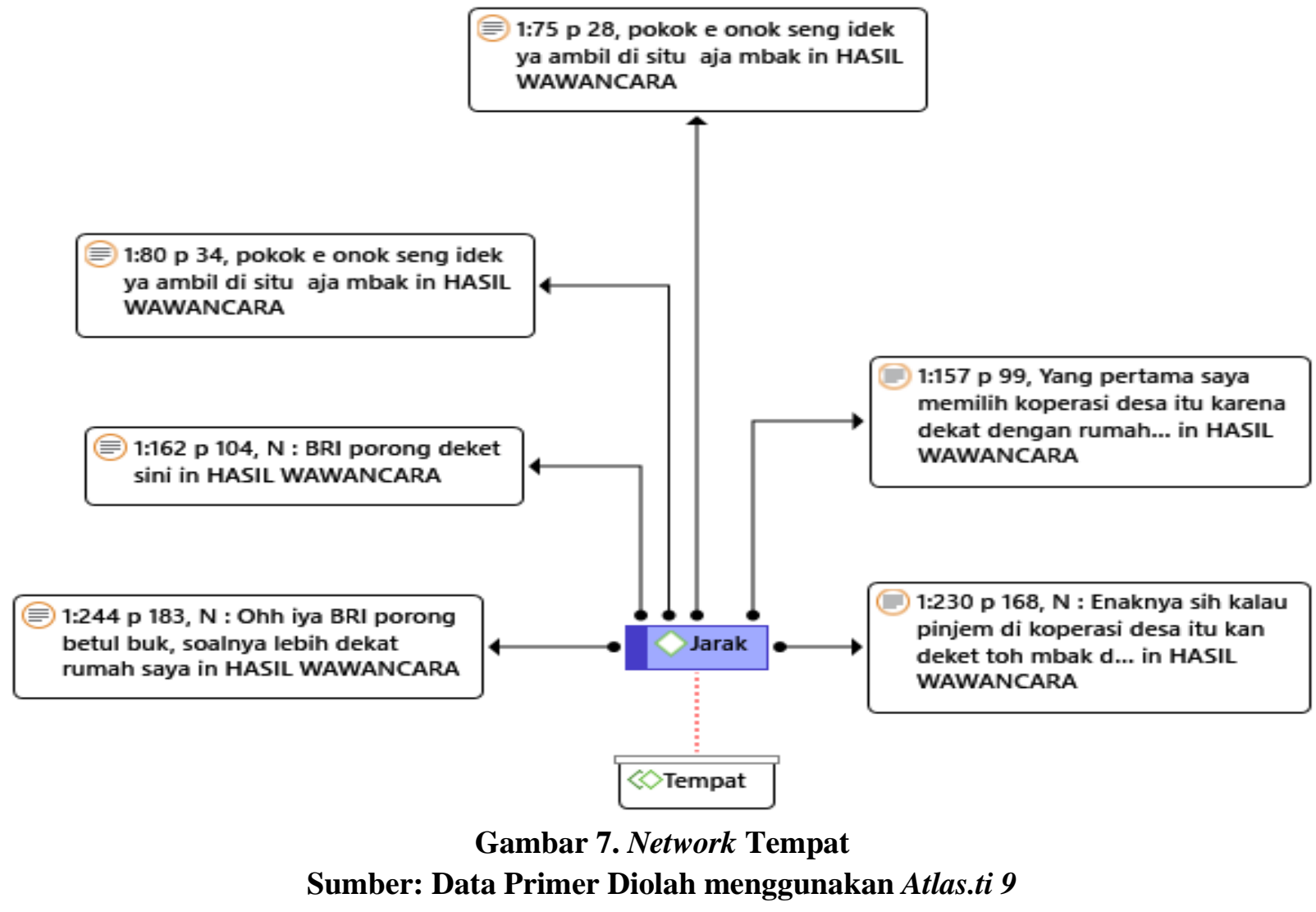

Dari gambar diatas dapat terlihat, bahwa mayoritas pedagang memilih meminjam di lembaga keuangan terdekat seperti pada koperasi desa tempat tinggalnya, maupun cabang bank BRI yang ada di kecamatan tempat tinggalnya. Hal ini dikarenakan selain menghemat waktu ketika proses pengajuan yang mungkin saja membutuhkan beberapa kali kunjungan,tetapi juga dapat menghemat biaya operasional yang dikeluarkan. Dekatnya jangakauan lembaga keuangan terhadap tempat tinggal nasabah memberikan nilai lebih karena lebih efektif dan efisien.

\section{Promotion (Promosi)}

Sebagian besar pedagang mengakui mengetahui produk pinjaman tersebut, dari marketing Bank secara langsung dan juga atas saran orang lain (saudara/teman) yang telah lebih dulu melakukan pinjaman di Bank tersebut. 


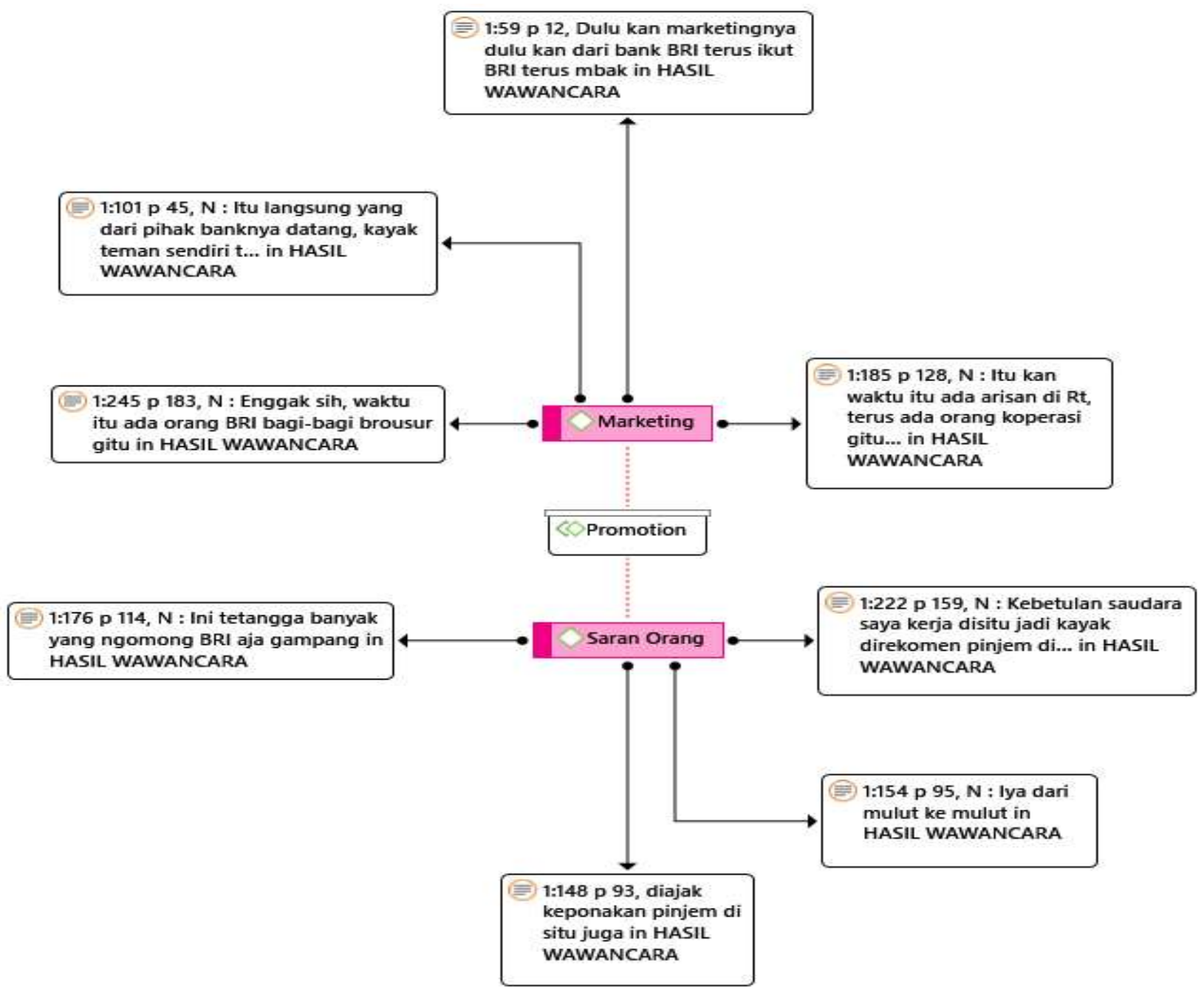

Gambar 8. Promosi

Sumber: Data Primer Diolah menggunakan Atlas.ti

Berdasarkan penuturan para pedagang, keputusannya memilih Bank Konvensional karena adanya saran dari orang lain. Beberapa pedagang mengatakan bahwa tetangganya menyarankan untuk melakukan pinjaman di BRI saja dikarenakan prosesnya mudah dan cepat. Kemudian juga adanya salah satu keluarga seperti keponakan yang telah lebih dulu meminjam di BRI turut memberikan saran untuk mengajukan pinjaman di BRI menggunakan dana KUR. Rata-rata informasi yang diperoleh pedagang pasar akan produk pinjaman modal usaha tersebut berasal dari mulut kemulut orang disekelilingnya. Adanya informasi-informasi secara lagsung dari pihak-pihak yang telah merasakan betul manfaatnya, tentu menjadi faktor penguat terhadap keputusan pedagang pasar untuk menentukan pilihan dimana mereka akan meminjam modal usaha.

Selanjutnya promosi yang dilakukan langsung oleh marketing bank. Beberapa pedagang mengakui mendapatkan informasi produk pinjaman modal usaha dari brosur-brosur yang dibagi-bagikan marketing secara langsung kepadanya. Kemudian tak sedikit marketing yang juga mendatangi para pedagang langsung ke tokonya guna menawarkan dan menjelaskan terkait produk pinjaman modal usaha, dan kebetulan mereka memang sedang butuh pinjaman modal. Selanjutnya, adanya rekomendasi dari saudara yang bekerja langsung di bank tersebut juga menjadi salah satu faktor yang menambah keyakinan pedagang untuk memilih sumber modal usaha.

\section{KESIMPULAN}

Kebutuhan menjadi pemicu awal bagi para pedagang pasar dalam mengajukan pinjaman modal usaha. Akan tetapi kebutuhan tersebut seringkali membuat pedagang mengabaikan hal-hal yang dapat menjerumuskan mereka kepada dosa besar, seperti Riba. Terlihat hasil analisis data diatas, meskipun mayoritas pedagang mengetahui hukum riba, dan 


\section{Jurnal Ilmiah Ekonomi Islam, 6(03), 2020, 701}

mengetahui eksistensi bank syariah, akan tetapi pengetahuan tersebut tidak mengubah keputusan mereka untuk beralih menggunakan produk pembiayaan yang ada di bank syariah maupun koperasi syariah. Sehingga perlu bagi lembaga keuangan syariah untuk dapat mencoba menggunakan pendekatan yang lebih komprehensif dalam memahami kebutuhan para pedagang. Lembaga keuangan syariah harus dapat bersaing dengan baik dengan lembaga keuangan konvensional agar dapat membantu dan menyelamatkan para pedagang pasar dari lilitan dosa riba yang berlandaskan kebutuhan. Penerapan bauran pemasaran $4 \mathrm{P}$ dapat menjadi alat bantu bagi lembaga keuangan syariah untuk dapat menarik minat masyarakat, dimana hal tersebut juga harus diiringi dengan dilakukannya segmentasi pasar yang lebih baik, agar benar-benar dapat menjadi solusi akan kebutuhan masyarakat terkait permodalan usaha. Pasalnya kecenderungan kebutuhan para pedagang adalah tidak menitik beratkan kepada pengetahuan riba, akan tetapi lebih kepada bagaimana cara memenuhi kebutuhannya dengan memilih penawaran manakah yang lebih cocok dan menguntungkan, baik dari segi produk, harga, tempat, dan promosi yang ditawarkan.

Sehingga hasil penelitian tersebut dapat memberikan gambaran bahwa pengetahuan pedagang mengenai riba dan bank syariah tidak berpengaruh terhadap keputusan pedagang dalam memilih lembaga keuangan, sedangkan faktor bauran pemasaran terbukti dapat menarik minat para pedagang dalam menentukan dimana mereka akan melakukan pinjaman sumber modal usaha. Meningkatkan kepercayaan masyarakat juga perlu dilakukan agar persepsi bank syariah sama saja dengan bank konvensional dapat berangsur-angsur hilang.

\section{UCAPAN TERIMA KASIH}

Terimakasih kepada Prodi Perbankan Syariah Fakultas Agama Islam Universitas Muhammadiyah Sidoarjo atas banyak ilmu dan pengalaman, serta kesempatan dan kemudahan yang diberikan kepada saya, terutama kepada bapak M. Ruslianor Maika sebagai dosen pembimbing yang telah memberikan banyak arahan dan masukan pada penulisan artikel ini. Serta kepada bapak editor dan para peer-reviewers yang telah menelaah dan mereview Jurnal Ilmiah Ekonomi Islam.

\section{REFERENSI}

Abbas, D. (2018). Pengaruh Modal Usaha, Orientasi Pasar, Dan Orientasi Kewirausahaan Terhadap Kinerja Ukm Kota Makassar. Jurnal Minds: Manajemen Ide Dan Inspirasi, 5(1), 95-111. https://doi.org/10.24252/minds.v5i1.4991

Andespa, R. (2017). Faktor-Faktor Yang Mempengaruhi Minat Nasabah Dalam Menabung Di Bank Syariah. Al Masraf: Jurnal Lembaga Keuangan Dan Perbankan, 2(1), 4356.

Fuad, M., H, C., Nurlela, Sugiarto, \& Paulus. (2006). Pengantar Bisnis. Jakarta: Erlangga.

Hakim, Y. P., \& Mulyani, S. (2017). Analisis Kebutuhan Modal Kerja Pada Rumah Makan Bintang Lima Di Samarinda. Jurnal Ekonomi Manajemen, 11(2).

Hamid, F. (2013). Pendekatan Fenomenologi Dalam Suatu Ranah Penelitian Kualitatif. Penelitian

Fakultas Saintek UIN Sunan Kalijogo Yogjakarta, 1(1), 1-15.

KNKS. (2020). TREND Tingkatkan Efisiensi dan Produktivitas Bisnis. (9), 11.

Maesaroh. (2016). Perilaku Masyarakat Dalam Memilih Pembiayaan. Al-Iqtishad: Journal of Islamic Economics, https://doi.org/10.15408/aiq.v2i2.2483

Munizu, M. (2012). Strategi Bauran Pemasaran dan Pengaruhnya Terhadap Keputusan Konsumen. Manajemen Teori Dan Terapan, 5(2), 2-8.

Nassaji, H. (2015). Qualitative And Descriptive Research: Data Type Versus Data Analysis. Language Teaching Research, 19(2), 129-132. https://doi.org/10.1177/1362168815572747

Palisoa, M. U., Andayani, S., \& Maduwinarti, A. (2009). Analisis Pengaruh Pendapatan, Gaya Hidup, dan Kebutuhan Terhadap Keputusan Menggunakan Kartu Kredit BCA di Surabaya.

Rahmawati, E. N., Kafid, N., \& Wijaya, T. (2017). Analisis Faktor Penyebab Rendahnya Minat Masyarakat Memilih Produk Pembiayaan Paa Bank Syariah. Anil Islam, 10(1), 3-24.

Rochmawan, L. T. (2008). Pengantar Ekonomi Mikro. Semarang: Anindya.

Saputra, A. D., \& Ghani, A. (2016). Analisis Pengaruh Pendidikan Dan Faktor Sosial Terhadap Pengetahuan Masyarakat Tentang Bank Syariah (Studi Kasus Di Dusun Pandean Pundung Wukirsari Imogiri Bantul). Ekonomi Syariah Indonesia, VI(1), 12-22. 
Jurnal Ilmiah Ekonomi Islam, 6(03), 2020, 702

Sefudin, A. (2014). Redefinisi bauran pemasaran (marketing mix) "4P" ke "4C" (Studi Kasus pada Universitas Indraprasta PGRI). Journal of Applied Business and Economics, 1(1), 17-23.
Winarni, M. C. (n.d.). Analisis Faktor-Faktor Yang Mempengaruhi Rendahnya Minat Masyarakat Terhadap Lembaga Keuangan Syariah. (Studi Kasus Pada Masyarakat di Kabupaten Grobogan). 